\title{
EMERGENCE OF CORN ACCORDING TO THE SOWING DEPTH OF THE SEED AND LOADS ON PRESS WHEELS
}

\section{PEDRO H. WEIRICH NETO ${ }^{1}$, ANGELO R. C. LOPES $^{2}$}

\begin{abstract}
The seeding process was the operation that suffered the most changes in no-tillage system due the cover crop soil and new particle soil arrangement. The objective of this study was to verify the effects of loads applied to the wheels and adjustments of sowing depth on seedling emergence of corn in no-tillage system. The experimental design was completely randomized with a factorial arrangement $5 \times 4$, with five loads applied to the wheels and four theoretical sowing depth adjustments. The real sowing depth increased in the lower theoretical depth and decreased in the higher theoretical depth, due to the compaction loads. Regarding the time of emergence, loads applied had not influence at the greater depths. Emergence time decreased with the load increase in the lower depths. Thus, the adjustment of the compactor wheels can influence in the corn seeding process.
\end{abstract}

KEYWORDS: seeding process, no-tillage, farm mechanization.

\section{EMERGÊNCIA DO MILHO CONFORME PROFUNDIDADE DE DEPOSIÇÃO DE SEMENTES E CARGA APLICADA NAS RODAS COMPACTADORAS}

RESUMO: Devido à presença da cobertura vegetal e ao novo arranjo das partículas do solo no sistema de plantio direto (SPD), o processo de semeadura foi a operação que sofreu as maiores transformações. Sendo assim, objetivou-se verificar o efeito de cargas aplicadas nas rodas compactadoras e de regulagens da profundidade na semeadura de milho em SPD. O delineamento utilizado foi o inteiramente aleatorizado, com arranjo fatorial $5 \times 4$, com cinco cargas aplicadas nas rodas compactadoras e quatro regulagens de profundidades teóricas de deposição de sementes. A profundidade real de deposição de sementes aumentou na menor profundidade teórica e diminuiu na maior profundidade teórica, conforme aumento das cargas de compactação. Quanto ao tempo de emergência, nas maiores profundidades teóricas, não houve influência da carga aplicada. Para as menores profundidades, o tempo de emergência diminui com o aumento da carga. Assim, a regulagem das rodas compactadoras pode influenciar no processo de semeadura do milho.

PALAVRAS-CHAVE: processo de semeadura, plantio direto, mecanização agrícola.

\section{INTRODUCTION}

The region of Campos Gerais, Parana stands out in the Brazilian agricultural landscape, as an example in the use and development of new technologies. In this context, it refers to the tillage system, a reality in the region. Due to the vegetation cover and new arrangement of soil particles in this system, the seeding process was the operation that suffered the greatest changes.

For types of soil tillage and cover crop variation, RAOUFAT \& MAHMOODIEH (2005) identified variation in deposition depth of seeds and maize plant population.

Studying emergency corn, GUPTA et al. (1988) observed that at favorable temperatures a positive linear correlation exists between the depth of seeding and the time required for

\footnotetext{
${ }^{1}$ Eng ${ }^{\circ}$ Agrícola., D.Sc., Professor Adjunto, Departamento de Ciência do Solo e Engenharia Agrícola, Universidade Estadual de Ponta Grossa - UEPG, Câmpus Uvaranas, Av. Carlos Cavalcanti ,4748, Ponta Grossa - PR, lama1 @uepg.br.

${ }^{2}$ Eng ${ }^{\mathrm{o}}$ Agrônomo, Insolo Gerenciamento Agrícola, Av. Contorno 555, Balsas - MA, angelo.lopes@ @insolo.com.br.

Recebido pelo Conselho Editorial em: 25-4-2011

Aprovado pelo Conselho Editorial em: 27-11-2011
} 
germination. However, YORINORI et al. (1996) described that without reporting the water content of the soil, was inverse.

Correlations between corn yield and heterogeneity of emergency have been described (NAFZIGER et al., 1991; FORD \& HICKS, 1992). MEROTTO JUNIOR et al. (1999) observed yield losses of around 2,900 kg ha ${ }^{-1}$ when there is occurrence of delay in the emergence of 12 days in 50\% of maize seedlings. LIU et al. (2004) reported having the highest correlation (negative) of corn yield variability with emergency than with the variability in the Plant distribution.

In the area under tillage, with soil clay content of $570 \mathrm{~g} \mathrm{~kg}-1$ in maize sowing, FEY (2000) observed that increasing the water content of soil $\left(0.22\right.$ to $\left.0.24 \mathrm{~g} \mathrm{~g}^{-1}\right)$ gave fewer seedlings. This was attributed to increased compaction caused by the wheels because of the change in water content, causing physical impairment to the emergency.

Working with four loads on the seed furrows in corn $(0,49,98$ and $147 \mathrm{~N})$ applied by cylindrical metal wheels, PRADO et al. (2001) observed a positive linear correlation between the emergence rate and the applied loads. In the study of SILVA et al. (2004a), with the soybean crop were evaluated three sowing depths and three loads $(68.6,137.2$ and 235.6 N) applied by wheels of type double, angled "V", coated with massive rubber, with no significant difference in the number of emerged plants in plant height at 26 and 36 days after sowing, or the productivity, a fact attributed to the absence of water stress and nutrition.

In an experiment carried out in maize were tested by SILVA et al. (2004 b), three models of wheels, subjected to loads of 50,100 and $150 \mathrm{~N}$, with sowing depth of 3,5 and $7 \mathrm{~cm}$. The authors found no interaction between factors, however, the sowing depth significantly affected the time of emergence and number of emerged plants.

Also doing studies with the position of seed and fertilizer, KARAYEL \& ÖZMERZI (2007) report preoccupation with scaling methodologies of the dependent variables of the sowing process. Therefore, it aimed at verifying the effect of loads applied to the wheels and the adjustments of sowing depth on seedling emergence of corn.

\section{MATERIAL AND METHODS}

The experiment was conducted at the Farm School 'Capão da Onça' of the Universidade Estadual de Ponta Grossa (UEPG), located in the city of Ponta Grossa - Parana with geographic coordinates $25^{\circ} 05^{\prime} 25^{\prime \prime}$ South and $50^{\circ} 03^{\prime} 24^{\prime \prime}$ West and altitude mean of $930 \mathrm{~m}$. The experiment was in a plot of the Experimental and Demonstration Field (EDF) with an area of $1000 \mathrm{~m}^{2}$, which had sand content of $616 \mathrm{~g} \mathrm{~kg}^{-1}, 280 \mathrm{~g} \mathrm{~kg}^{-1}$ of clay and $104 \mathrm{~g} \mathrm{~kg}^{-1}$ of silt, and $3.8 \mathrm{Mg} \mathrm{ha}^{-1}$ on average, of dry vegetal mass coverage (oat and maize). The seeds were sown on February $23^{\text {rd }}$. The hybrid used was denominated 30P70 (Pioneer ${ }^{\circledR}$ Seed). No fertilize was used.

It was used precision planter Semeato ${ }^{\circledR}$ brand model PS8, which was adjusted to 6.6 seeds per $\mathrm{m}$. It was used eight lines of drill, spaced at $0.45 \mathrm{~m}$. This spacing was used because it was not followed the complete cycle of the culture. The furrow openers were double-disc type offset for fertilizer and double-disc for seed furrow opening. The system of furrow sowing compaction consisted of two metal wheels coated with solid rubber with "V" angle of about $60^{\circ}$. The regulation of the compaction system is given by the traction of a helical spring. The tractor used was a Massey Ferguson ${ }^{\circledR}$ model 5320, with $88.2 \mathrm{~kW}$ engine power.

The experimental design was completely randomized in factorial scheme $4 \times 5$ with four replications, being studied the seeding depth and the applied load on the wheels. It was used the denomination, load 1, load 2, load 3, load 4 and load 5 for increasing traction of the spring. The depth adjustments were made in order to achieve the deposition of seeds theoretically to $2 ; 3 ; 4$ and $5 \mathrm{~cm}$, denominated deep adj. 2, deep adj. 3, deep adj. 4 and deep adj. 5, respectively. The treatments were arranged in the drill so that each of the eight distributor systems would receive at least once of each treatments. 
The level of compression applied by the wheels was through static test. In an analog scale capacity of $2000 \mathrm{~N}$ set on the ground surface so that the weighing stand in the ground level, it was selected three rows of the drill, and in each row was determined the mass applied by the wheels compactors, in the five load adjustments, in each of the four adjustments depth used.

To determine the water content in the soil at planting, the soil was sampled at depths $0-5 \mathrm{~cm}$ and $5-10 \mathrm{~cm}$. To this, it was selected six sites in the plot and collected four samples with an auger hole type. The determination of water content was performed at EMBRAPA (1997). To determine the susceptibility of soils to compaction it took place the Proctor test (MARTINS JUNIOR, 1964). As dependent variable, three days after sowing, began determining the emergence of seedlings, which were held both in the morning and in the afternoon, in the central $4 \mathrm{~m}$ of each sowing row which was $12 \mathrm{~m}$ until the 14th day after sowing. The actual depth of sowing was verified by cutting the seedlings near the soil surface, digging them and measuring the cut until the embryo of the seed. The number of samples (seedlings) was unbalanced ranging from 17 to 26 per plot.

With data from seedling emergence, we calculated the average time of emergence in each treatment and the emergence speed index (ESI) (NAKAGAWA, 1994).

The variables, actual mass applied by the wheels, real depth of sowing, time to seedling emergence and emergence rate index, were submitted to variance analysis and after average test. It was used for analysis the computer program Minitab ${ }^{\circledR}$ statistical 12.2.

\section{RESULTS AND DISCUSSION}

The temperature of the air and precipitation obtained in the weather station located at $500 \mathrm{~m}$, for the duration of the experiment are shown in Figure 1.

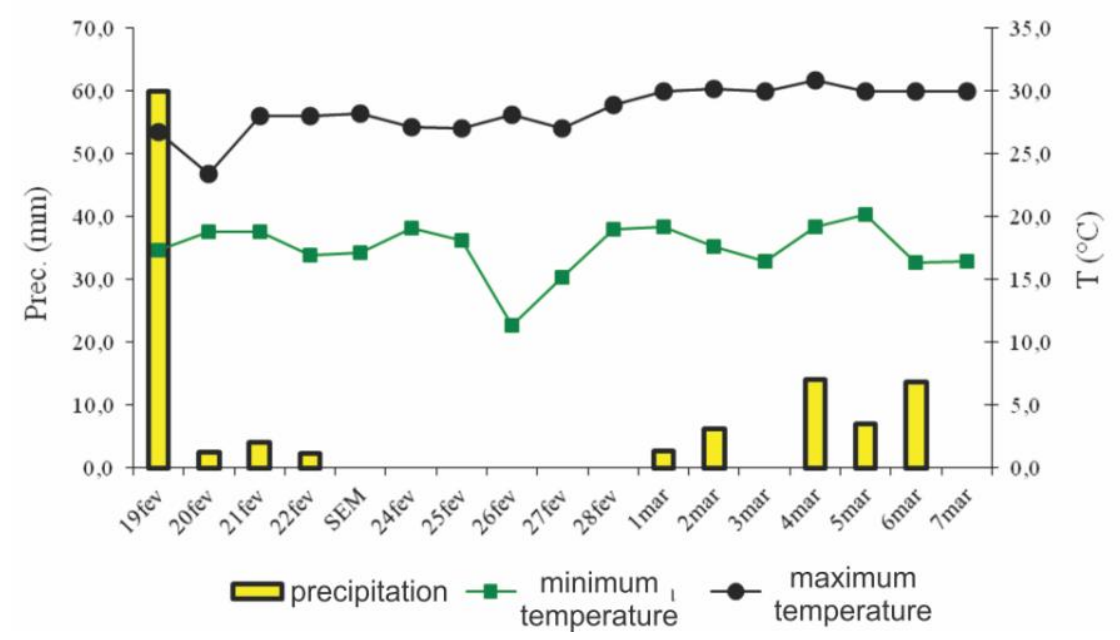

FIGURE 1. Precipitation, maximum and minimum temperatures in the period before sowing (SEM) and seedling emergence (12 days after sowing).

Values of water content in the soil at the time of seeding were $150 \mathrm{~g} \mathrm{~kg}^{-1}$ at the depth of 0-5 $\mathrm{cm}$ and $190 \mathrm{~g} \mathrm{~kg}^{-1}$ at 50-100 mm. REIS et al. (2002) found no difference in the emergence and emergence rate index for soil water content ranging from 290 to $420 \mathrm{~g} \mathrm{~kg}^{-1}$ in maize sown $6 \mathrm{~cm}$ depth.

Figure 1, also shows that the temperature values during the experiment can be considered as favorable for the germination of corn, being among the cardinal temperatures suitable for this process to occur. It should be mentioned that only on the third day after sowing, the temperature has reached below $15^{\circ} \mathrm{C}$, reaching $11.3^{\circ} \mathrm{C}$. GUPTA et al. (1988) observed that at temperatures favorable, there is a positive linear correlation between the depth of seeding and the time for the emergence of corn seedlings. 
With regard to the forces applied as adjustments for spring tension (load), there was a statistical difference, not occurring interaction with the sowing depth (Table 1). The load treatments 1 and 2 did not differ statistically. This can be attributed to the fact that the wheels are connected to the controlling mechanism of depth, which at the time of the determination of the forces causes them to be pulled up, as well as inefficiency of the project, where the difference of the spring can not provide the resulting difference in the system. Thus, for the two settings in question, the values found probably correspond only to the action of gravity on the mass of the wheel, not having, in this case, the effect of the spring tensioning. In all the pressure there were differences between the forces for adjustments in depth, being the deep adj. 2 lower than the others.

TABLE 1. Static force applied by press wheels accordingly to adjustments of the theoretical loads on press wheels and sowing depth.

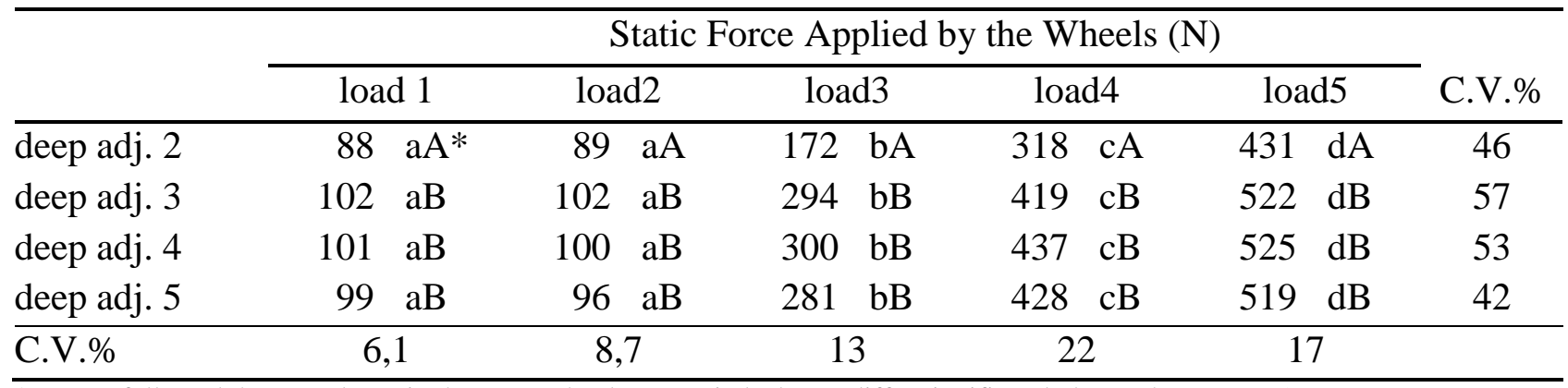

* Means followed the same letter in the row and column capitals do not differ significantly by Turkey test at 5\%

Given that the test that originated in Table 1 was performed statically, it is noteworthy that dynamically due to rolling terrain and full operation of the furrowing this table may differ to the settings closer.

Figure 2 shows the relationship between water content of the soil and its bulk density according to the Proctor test.

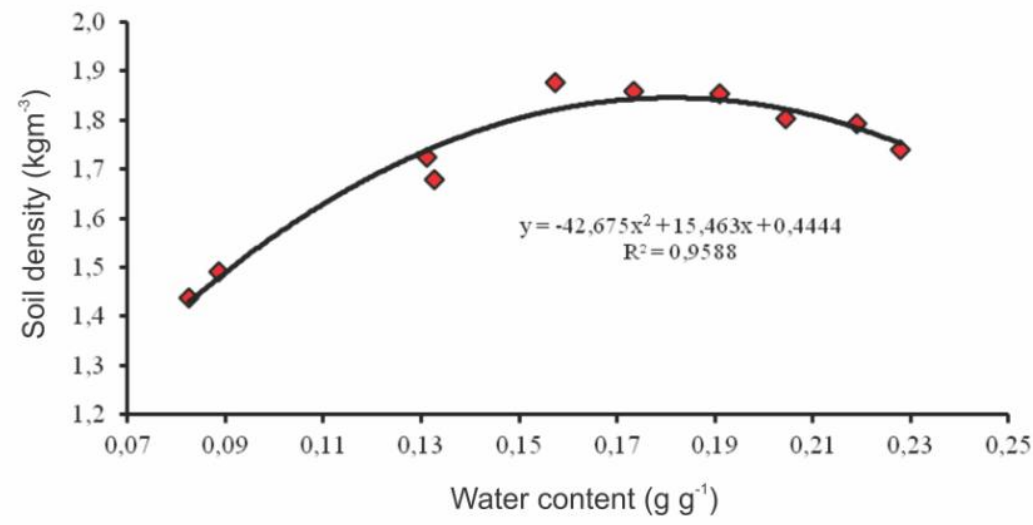

FIGURE 2. Regression curve and determined points according to the Proctor test for the soil of the plot where experiment was carried out.

Through equal to zero the first derivative of the equation chosen to represent the phenomenon, was determined the point of maximum specific gravity of the soil according to the methodology used (Figure 2). As equation, the greater susceptibility of compression of the experimental area occurs when the soil water content is $0.181 \mathrm{~g}^{-1}$. According to water content at the time of seeding, $0.15 \mathrm{~g} \mathrm{~g}^{-1}$ and $0.19 \mathrm{~g} \mathrm{~g}^{-1}$ at in the depths $0-5 \mathrm{~cm}$ and $5-10 \mathrm{~cm}$, respectively, can be considered that the soil is presented in a condition close to its maximum compaction susceptibility.

For the variable depth real seed deposition there was a significant interaction between factors. In deep adj. 2 statistical difference between load $1(88.2 \mathrm{~N})$ and the others, in this case, the increase in compaction provided to increase the depth of approximately $0.5 \mathrm{~cm}$ (Table 2). The press 
wheel, even in a lateral position to the seed, pressed the seed down. However, it was expected that the difference in the actual sowing depth was not found between load $1(88.2 \mathrm{~N})$ and load $2(89.1 \mathrm{~N})$, which was discussed earlier. This demonstrates that even small changes in the adjustments of the theoretical variables can change the dependent variables of sowing.

TABLE 2. Real sowing depth of corn seeds $(\mathrm{cm})$, according to the variation of the theoretical sowing depth adjustment and loads on press wheels.

\begin{tabular}{|c|c|c|c|c|c|c|}
\hline \multirow[b]{3}{*}{ deep adj. 2} & \multicolumn{5}{|c|}{ Sowing Depth $(\mathrm{cm})$} & \multirow[b]{2}{*}{$\mathrm{CV} \%$} \\
\hline & Load 1 & Load 2 & Load 3 & Load 4 & Load 5 & \\
\hline & $1.5 \mathrm{aA}^{*}$ & $2.0 \mathrm{bA}$ & $\mathrm{bA}$ & 1.9 & $2.1 \quad \mathrm{bA}$ & 45 \\
\hline deep adj. 3 & $2.5 \mathrm{abB}$ & $2.8 \mathrm{aA}$ & 2.1 & 2.2 & $\mathrm{aAB}$ & 63 \\
\hline deep adj. 4 & $2.7 \quad \mathrm{aB}$ & $3.1 \mathrm{bB}$ & 2.5 & $2.7 \mathrm{abB}$ & $2.8 \mathrm{abB}$ & 31 \\
\hline deep adj. 5 & 4.1 & $4.1 \mathrm{aC}$ & $3.7 \mathrm{abC}$ & $3.5 \mathrm{bC}$ & $3.5 \mathrm{bC}$ & 19 \\
\hline C.V.\% & 46 & 57 & 38 & 40 & 41 & \\
\hline
\end{tabular}

* Means followed the same letter in the row and column capitals do not differ significantly by Turkey test at 5\%

In the case of deep adj. 5, there were also significant differences in the actual depth of deposition between the settings of loads. It was found that increasing the weight applied by the wheels in the planting furrow of $98.98 \mathrm{~N}$ (load 1) to $428.2 \mathrm{~N}$ (load 4) gave a decrease in the sowing depth of $0.6 \mathrm{~cm}$ (Table 2.) It is worth noticing that in this case, increasing the load exerted by the wheels exerted a force which, in the final composition may have the effect of raising the seed line, reducing the depth of the seed. Another hypothesis is the occurrence of lateral load shifting soil and seed ground up.

The variable time of emergency, is noted in Table 3 that the seedlings emerged in all treatments over a period of 5-10 days after sowing. These results agree with GUPTA et al. (1988), who observed in favorable conditions of water temperature and emergence of corn seedlings in 5.9 days, with standard deviation of 0.4 days, and in adverse conditions seedling emergence in 28 days. In this case, there was an interaction between these factors. It was observed statistical difference in time of emergency in deep adj. 2 and deep adj. 3, for deep adj. 2, the increasing of the load of $88.2 \mathrm{~N}$ to $431.2 \mathrm{~N}$ and also have provided an increase in the sowing depth of $1.5 \mathrm{~cm}$ to $2.1 \mathrm{~cm}$ (Table 2) may have provided better contact between soil-seed, reducing the time of emergency in 2.3 days (Table 3). Regarding the results already discussed, SILVA et al. (2004b) found no interaction for variable emergence time between loads of $50 \mathrm{~N}, 100 \mathrm{~N}$ and $150 \mathrm{~N}$ in corn seeding to $3 ; 5$ and $7 \mathrm{~cm}$ deep.

TABLE 3. Time to corn seedling emergence (days) according to the sowing depth adjustments and loads on press wheels.

\begin{tabular}{|c|c|c|c|c|c|c|c|c|c|}
\hline & \multicolumn{8}{|c|}{ Emergency Time (days) } & \multirow[b]{2}{*}{$\mathrm{CV} \%$} \\
\hline & Load 1 & Load 2 & \multicolumn{2}{|c|}{ Load 3} & \multicolumn{2}{|c|}{ Load 4} & \multicolumn{2}{|c|}{ Load 5} & \\
\hline deep adj. 2 & $9.4 \quad \mathrm{aA}^{*}$ & $7.8 \mathrm{bcA}$ & & $\mathrm{bA}$ & & $\mathrm{bcA}$ & 7.1 & $\mathrm{cA}$ & 26 \\
\hline deep adj. 3 & $7.3 \mathrm{abB}$ & $7.8 \quad \mathrm{aA}$ & 7.0 & $\mathrm{abAB}$ & 7.5 & $\mathrm{abA}$ & 6.7 & $\mathrm{bAB}$ & 27 \\
\hline deep adj. 4 & $6.2 \mathrm{aC}$ & 6.3 & 6.3 & $\mathrm{aAB}$ & 6.4 & $\mathrm{aB}$ & 6.1 & $\mathrm{aB}$ & 20 \\
\hline deep adj. 5 & $5.6 \mathrm{aC}$ & $5.6 \mathrm{aB}$ & 5.5 & $\mathrm{aB}$ & 5.8 & & 5.8 & & 13 \\
\hline C.V.\% & 30 & 27 & & 26 & & & & & \\
\hline
\end{tabular}

* Means followed by the same uppercase and lowercase in the column on the line do not differ significantly by Tukey test at $5 \%$

For deep adj. 3 to maximum difference in time of emergence was about 1 day, between the load $5(522.3 \mathrm{~N})$ and load $2(102.9 \mathrm{~N})$. For deep adj. 5, even with a significant difference in the 
actual depth of sowing of load $1(98.9 \mathrm{~N})$ of $4.1 \mathrm{~cm}$ to $3.5 \mathrm{~cm}$ in load $5(519.4 \mathrm{~N})$, there was no significant difference in the time of emergence (Table 3).

With respect to levels of precipitation during the experiment (Figure 1), there is a six-day period without the occurrence of rainfall after sowing. Knowing that the topsoil is first to enter a state of drought, it is expected that more superficially deposited seeds have their germination process inhibited. In this case, the increased compression on the ground, on the seeds can minimize the so-called water stress. This is represented in the deep adj. 2, by the decrease in the time of seedling emergence with the increase in the pressure in the planting furrow in this depth.

To the emergence speed index of seedling (ESI), no significant interaction was found between the factors, only statistical difference between the adjustments of the depth. In treatments deep adj. 4 and deep adj. 5 obtained the highest ESI, being only load 1 the values not statistically equal to those found for deep adj. 4 (Table 4). Unlike the variable time of emergency that was influenced by the increased load on the wheels in deep adj. 2 and deep adj. 3, for the variable ESI increasing has not been observed for these adjustments depth (Table 4). PRADO et al. (2001) observed no interaction between compression and sowing depth, concluding that these two factors act independently on the ESI for corn. As Table 4 shows that the ESIS for deep adj. 2 and deep adj. 3 in load 1 were low and equal. However, to these same adjustments, is observed in Table 3 that the time of emergence was different. In deep adj. 3, the plants took longer (9.4 days on average), but the time between the emergence of the first and last seedling was very close.

TABLE 4. Emergence speed index (ESI) according to the variation of the seeding depth and loads on press wheels.

\begin{tabular}{|c|c|c|c|c|c|c|c|c|c|}
\hline \multirow[b]{3}{*}{ deep adj. 2} & \multicolumn{8}{|c|}{ Emergency speed index (ESI) } & \multirow[b]{2}{*}{$\mathrm{CV} \%$} \\
\hline & Load 1 & Load 2 & \multicolumn{2}{|c|}{ Load 3} & \multicolumn{2}{|c|}{ Load 4} & \multicolumn{2}{|c|}{ Load 5} & \\
\hline & $0.3 \quad \mathrm{aA}^{*}$ & 0.7 & 0.8 & $\overline{\mathrm{aA}}$ & 1 & $\mathrm{aA}$ & 1.3 & $\mathrm{aA}$ & 31 \\
\hline deep adj. 3 & $0.8 \quad \mathrm{aA} *$ & 0.8 & 1.2 & $\mathrm{aAB}$ & 1.6 & $\mathrm{aAB}$ & 1.4 & $\mathrm{aA}$ & 22 \\
\hline deep adj. 4 & $3.2 \mathrm{aB}$ & 2.9 & 3.1 & $\mathrm{aB}$ & 3.5 & $\mathrm{aB}$ & 2.7 & $\mathrm{aAB}$ & 16 \\
\hline deep adj. 5 & $4.6 \mathrm{aC}$ & 4.4 & 3.1 & $\mathrm{aB}$ & 3.5 & $\mathrm{aB}$ & 3.8 & & 27 \\
\hline C.V.\% & 74 & 52 & \multicolumn{2}{|c|}{41} & \multicolumn{2}{|c|}{46} & \multicolumn{2}{|c|}{36} & \\
\hline
\end{tabular}

* Means followed by the same uppercase and lowercase in the column on the line do not differ significantly by Tukey test at $5 \%$

\section{CONCLUSIONS}

There was an increase of the actual depth of $0.6 \mathrm{~cm}$ as increased the loads applied to the lowest adjustment of theoretical depth (deep adj. $2 \mathrm{~cm}$ ). For the highest theoretical depth adjustment (deep adj. $5 \mathrm{~cm}$ ), there was a reduction of real depth of $0.6 \mathrm{~cm}$ according to the increase of applied loads.

The emergence time decreases with increasing the loads of the wheels for smaller theoretical depth adjustment, deep adj. 2 and $3 \mathrm{~cm}$, in 2.3 and 0.6 days respectively.

The emergence speed index increased with the increasing the theoretical depth adjustment.

The adjustment of the wheels is an important factor in the process of corn in Tillage System, which can affect the depth of sowing and time of emergence.

\section{REFERENCES}

EMBRAPA. EMPRESA BRASILEIRA DE PESQUISA AGROPECUÁRIA. Centro Nacional de Pesquisa de Solos. Manual de métodos de análise de solo. Rio de Janeiro: EMBRAPA-CNPS, 1997. $212 \mathrm{p}$. 
FEY, E. Desempenho de mecanismos sulcadores utilizados para a semeadura sob a palha em solo de textura argilosa com diferentes teores de água. 2000. 109 f. Dissertação (Mestrado em Engenharia de Sistemas Agroindustriais) - Universidade Estadual do Oeste do Paraná, Cascavel, 2000.

FORD, J.H.; HICKS, D.R. Corn growth and yield in uneven emerging stand. Journal of Production Agriculture, Madison, v.5, n.9, p.185-189, 1992.

GUPTA, S. C.; SCHENEIDER, E. C.; SWAN, J. B. Planting depth and tillage interactions on corn emergence. Soil Science Society of American Journal, Madison, v.52, n. 4, p.1122-1127, 1988.

KARAYEL, D.; ÖZMERZI, A. Comparison of vertical and lateral seed distribution of furrow openers using a new criterion. Soil \& Tillage Research, Amsterdam, v.95, p.69-75, 2007.

LIU, W.; TOLLENAR, M.; STEWART, G.; DEEN, W. Response of corn grain yield to spatial and temporal variability in emergence. Crop Science, Madison, v.44, n.3, p.847-854, 2004.

MARTINS JUNIOR, J. X. Métodos de ensaios. Brasília: Departamento Nacional de Estradas de Rodagem, 1964. 206 p.

MEROTTO JUNIOR, A.; SANGOI, L.; ENDER, M.; GUIDOLI, A. F.; HAVERROTH, H. S. A desuniformidade de emergência reduz o rendimento de grãos do milho, principalmente em alta população de plantas. Ciência Rural, Santa Maria, v.29, n.4, p.595-601, 1999.

NAFZIGER, E. D.; CARTER, P. R.; GRAHAM, E. E. Response of corn uneven emergence. Crop Science, Madison, v.31, n.3, p.811-815, 1991.

NAKAGAWA, J. Testes de vigor baseados na avaliação de plântulas. In: VIEIRA, R. D.; CARVALHO, N. M. (Ed.). Testes de vigor em sementes. Jaboticabal: FUNEP, 1994. p.49-86.

PRADO, R. M.; TORRES, J. L.; ROQUE, C. G.; COAN, O. Semente de milho sob compressão do solo e profundidades de semeadura: influência no índice de velocidade de emergência. Scientia Agrária, Curitiba, v.2, n.1, p.45-49, 2001.

RAOUFAT, M. H.; MAHMOODIEH, R. A. Stand establishment responses of maize to seedbed residue, seed drill coulters and primary tillage systems. Biosystem Engineering, v.90, n.3, p.261269, 2005. Disponível em: <http://www.sciencedirect.com/science?_ob=MiamiImageURL\&_cid=2 72441\&_user=3449831\&_pii=S153751100400217X\&_check=y\&_coverDate $=20050301 \& v i e w=c$ $\& w c h p=d G L z V l t z S k W b \& m d 5=e 75167980 \mathrm{e} 8 \mathrm{e} 88 \mathrm{~d} 69 \mathrm{e} 645 \mathrm{f5c} 97 \mathrm{a} 393 \mathrm{da} / 1-\mathrm{s} 2.0-$ S153751100400217X-main.pdf>. Acesso em: 2 ago. 2010.

REIS, E. F. dos.; SCHAEFER, C. E. G. R.; VIEIRA, L. B.; SOUZA, C. M.; FERNANDEZ, H. C. Avaliação do contato solo-semente em um solo argiloso sob plantio direto, com diferentes teores de água do solo. Engenharia na Agricultura, Viçosa-MG, v.10, n.1-4, p.31-39, 2002.

SILVA, R. P. da.; CORÁ, J. E.; CARVALHO FILHO, A.; LOPES, A.; FURLANI, C. E. A. Efeito de rodas compactadoras submetidas a cargas verticais em profundidades de semeadura sobre $\mathrm{o}$ desenvolvimento do milho. Engenharia Agrícola, Jaboticabal, v.24, n.2, p.396-404, 2004b.

SILVA, R. P. da.; TEIXEIRA, F. A. C.; CAMPOS, M. A. O. Efeito da profundidade de semeadura e da carga sobre a roda compactadora no desenvolvimento da soja (Glycine max). Engenharia na Agricultura, Viçosa-MG, v.12, n.3, p.169-176, 2004a.

YORINORI, N. A.; SADA, S.; PISAIA, A. E. Efeito da profundidade de semeadura e do envelhecimento precoce de sementes de milho-pipoca (Zea mays L.) sobre a emergência e vigor de plantas. Revista do Setor de Ciências Agrárias, Curitiba, v.15, n.2, p.173-178, 1996. 